\title{
PENUNDAAN PEMBAGIAN WARISAN PADA MASYARAKAT MUSLIM DI KOTA LANGSA
}

\author{
Lia Dahliani, Faisar Ananda, Ansari Yamamah \\ Pascasarjana UIN Sumatera Utara \\ Email: liadahliani09@gmail.com
}

\begin{abstract}
ABSTRAK:
Terdapat beberapa cara yang dilakukan masyarakat muslim dalam menyelesaikan permasalahan pembagian warisan di Kota Langsa, yaitu dengan cara musyawarah atau kekeluargaan baik melibatkan keluarga saja maupunpun melibatkan perangkat desa, dan cara terakhir yaitu melalui Mahkamah Syar'iyah Langsa. Banyak masyarakat kota Langsa yang menunda-nunda membagikan harta warisan. Faktor atau alasan masyarakat Kota Langsa menunda pembagian warisan yaitu: kesepakatan seluruh ahli waris; ahli waris banyak yang masih kecil atau belum waktunya mendapatkan warisan; beberapa pihak ingin menguasai harta warisan sehingga tidak ada atau ditundanya pembagian warisan itu; sebagian besar masyarakat menganggap membahas masalah warisan setelah pewaris meninggal adalah tabu; masih hidupnya salah satu ayah atau ibu pewaris sehingga ditunda pembagian warisan. Dampak penundaan pembagian warisan yang dilakukan masyarakat di Kota Langsa, yaitu sebagai berikut: terjadi konflik diantara ahli waris, baik itu konflik ringan sampai konflik berat; adanya hak-hak ahli waris yang berkurang dari bagian yang seharusnya diterima; adanya ahli waris yang tidak bisa merasakan harta warisan karena meninggal sebelum harta warisan itu sempat dibagikan; putusnya silaturahmi atau persaudaraan antara ahli waris karena perebutan harta warisan.
\end{abstract}

Kata kunci: Penundaan, pembagian warisan, konflik

\section{ABSTRACT:}

There are several ways that the Muslim community in solving the problem of division of inheritance in the city of Langsa, that is by way of musyawarah or kinship both involve family or even involving the village device, and the last way is through the Court Syar'iyah Langsa. Many Langsa city residents are procrastinating their inheritance. Factor or reason Langsa City society postpone the division of inheritance that is: agreement of all heirs; the heirs of many who are young or have not yet been given an inheritance; some parties want to take possession of the estate so that there is no or delayed distribution of the inheritance; most societies consider discussing inheritance after heirs are taboo; still life of one of the father or mother of the heir so that postponed the division of inheritance. The impact of delay in distribution of inheritance made by the community in Langsa City, as follows: conflict between the heirs, whether mild conflict to severe conflict; the existence of reduced heirs rights of the part which should be accepted; the existence of heirs who can not feel the inheritance due to death before the inheritance had been distributed; the breaking of the relationship or the brotherhood between the heirs due to the seizure of inheritance.

Keyword: delay, division of inheritance, conflict. 


\section{Tahkím}

Vol. XIV, No. 1, Juni 2018

\section{Pendahuluan}

Menurut hukum kewarisan Islam, rukun kewarisan ada tiga, yaitu: muwarri (pewaris), wāri (ahli waris) dan mauru (harta warisan). Muwarri (pewaris) adalah orang yang meninggal dunia, yang hartanya diwarisi oleh ahli warisnya. Istilah ini sering juga disebut mawari . 'Wāri (ahli waris) yaitu mereka yang berhak menerima harta peninggalan pewaris, dikarenakan hubungan kekerabatan atau hubungan perkawinan. ${ }^{2}$ Mauru (harta warisan) yaitu harta benda yang menjadi warisan. AlMauru dinamakan juga mirā dan ir , yaitu harta yang ditinggalkan oleh orang yang mewariskan atau hak-hak yang mungkin diwariskan. ${ }^{3}$ Para ulama telah sepakat bahwa ada beberapa tindakan yang harus dilakukan mendahului pembagian harta warisan. Pertama, biaya pengurusan jenazah. Kedua, pembayaran utang pewaris. Ketiga, menyerahkan wasiat. Setelah kewajiban terhadap harta yang ditinggalkan telah dilaksanakan sebagaimana dijelaskan sebelum ini dan ternyata masih ada harta yang tersisa, maka harta yang tersisa itu menjadi hak penuh bagi ahli waris. ${ }^{4}$

Penulis tidak menemukan dalil baik dalam Alquran maupun hadis yang secara tegas mengatakan bahwa harta warisan harus segera dibagikan, namun menurut penulis harta warisan tersebut harus segera dibagikan. Karena penulis melihat dari sisi kemaslahatan yang terkandung di dalamnya apabila harta warisan tersebut segera dibagikan setelah diselesaikan hak-hak atas pewaris seperti biaya jenazah, pelunasan utang dan wasiat. Di Kota Langsa, masih banyak masyarakat yang tidak langsung membagikan harta peninggalan pewaris. Setelah biaya pengurusan jenazah, kemudian mereka melunasi utang yang ditinggalkan pewaris. Sebagian masyarakat kota Langsa menunda pembagian warisan hingga bertahun-tahun lamanya bahkan sampai ada beberapa ahli waris yang meninggal sebelum warisan itu sempat dibagikan.

Tulisan ini membahas penundaan pembagian warisan pada masyarakat Muslim di Kota Langsa. Sumber utama pembahasannya adalah wawancara langsung dengan narasumber. Adapun yang menjadi lokasi penelitian ini adalah Kota Langsa, Aceh. Penelitian ini merupakan penelitian hukum empiris atau lapangan, dan pendekatan yang digunakan adalah pendekatan empiris dan pendekatan sosiologis, serta menggunakan metode analisis deskriptif.

Penundaan pembagian warisan telah banyak diteliti, namun tidak satupun ditemukan kajian yang khusus membahas penundaan pembagian warisan pada masyarakat Muslim di Kota Langsa. Kajian tentang penundaan pembagian warisan sebagaimana dilakukan oleh Yunisa Sonya Ratnani, Rahadyan Setiawan, Fabry Isman, Endah Mayana. Yunisa Sonya Ratnani membahas tentang Tradisi Penundaan Pembagian Warisan setelah Pendak di Desa Kepuhkembeng Peterongan Jombang Perspektif 'urf. Rahadyan Setiawan membahas tentang Pelaksanaan Pembagian Kewarisan menurut Hukum Islam (Study pada Pengadilan Agama Sleman). Fabry

${ }^{1}$ A. Rachmad Budiono, Pembaruan Hukum Kewarisan Islam di Indonesia (Bandung: PT. Citra Aditya Bakti, 1999), h. 9.

${ }^{2}$ Beni Ahmad Saebani, Fiqh Mawaris (Bandung: Pustaka Setia, 2009), h. 129.

${ }^{3}$ Wahbah Az-Zuhaili, Fiqih Islam Wa Adillatuhu, Jilid X, terj. Abdul Hayyie al-Kattani, dkk., (Jakarta: Gema Insani, 2011), h. 346. Lihat pula Komite Fakultas Syariah Universitas Al-Azhar, Mesir, Hukum Waris, terj. Addys Aldizar dan Fathurrahman, (Jakarta: Senayan Abadi Publishing, 2004), h. 28.

${ }^{4}$ Amir Syarifuddin, Hukum Kewarisan Islam, (Jakarta: Prenada Media, 2004), h. 278. 


\section{Tahkim}

Vol. XIV, No. 1, Juni 2018

Isman membahas tentang Analisis Yuridis Bercampurnya Harta Warisan dengan Harta Pribadi dalam Hukum Islam: Studi Kasus Putusan Pengadilan Mahkamah Syari'ah Bireuen No. 297/pdt.g/2012/ms-bireuen. Endah Mayana membahas tentang Analisis Yuridis terhadap Pelaksanaan Pembagian Harta Warisan yang Dikuasai oleh Salah Satu Ahli Waris (Studi Kasus Putusan Mahkamah Agung No. 2134/K/PDT/ 1989). Karenanya tulisan ini diharapkan berkontribusi memperkaya perdebatan tentang penundaan pembagian warisan pada masyarakat muslim di Kota Langsa.

\section{Landasan Teori}

Peneliti merasa bahwa perbincangan mengenai dampak penundaan pembagian waris memerlukan teori yang tepat, yaitu teori konflik, teori keadilan dan teori maqa id syari'ah. Teori pertama yang penulis gunakan adalah teori konflik. Konflik artinya percekcokan, perselisihan, pertentangan. ${ }^{5}$ Dalam hal ini pertentangan antara dua pihak atau lebih. Konflik dapat terjadi antar individu, antara kelompok kecil, bahkan antar bangsa dan negara. ${ }^{6}$ Dampak konflik pada umumnya negatif. Misalnya, anak yang mempunyai orang tua yang terus menerus bertengkar akan berkurang kepekaan afeksinya, tetapi mudah terpengaruh prilakunya. Konflik intertim olahraga atau di dalam perusahaan akan mengurangi prestasi kelompok, dan konflik antar bangsa dapat menyebabkan perang yang menimbulkan banyak korban jiwa. Terkait dengan penelitian ini penulis akan melihat bagaimana konflik yang timbul akibat dari penundaan pembagian waris di kota Langsa dan penulis juga akan menganalisa faktor-faktor yang menyebabkan konflik itu terjadi.

Kedua, penulis menggunakan teori keadilan menurut pandangan Aristoteles. Pandangan-pandangan Aristoteles tentang keadilan biasa ditemukan dalam karyanya Nicomachean ethics, Politics, dan Rethoric. Pandangan Aristoteles yang paling penting adalah bahwa keadilan mesti dipahami dalam pengertian kesamaan. Namun ia membuat perbedaan antara kesamaan numerik dan kesamaan proporsional. Kesamaan numerik mempersamakan setiap manusia sebagai satu unit. Inilah yang sekarang bias kita pahami tentang kesamaan dan yang kita maksudkan ketika mengatakan bahwa semua warga adalah sama di depan hukum. Kesamaan proporsional memberi tiap orang apa yang menjadi haknya sesuai dengan kemampuannya, prestasinya, dan sebagainya. ${ }^{7}$

Menurut Aristoteles dalam teorinya menyatakan bahwa ukuran keadilan adalah: Pertama, seseorang tidak melanggar hukum yang berlaku, sehingga keadilan berarti sesuai dengan hukum (lawfull), yaitu hukum tidak boleh dilanggar dan aturan hukum harus diikuti. Kedua, seseorang tidak boleh mengambil lebih dari haknya, sehingga keadilan berarti persamaan hak (equal). ${ }^{8}$ Dalam hukum kewarisan Islam, asas keadilan mengandung pengertian adanya keseimbangan antara hak yang diperoleh dan harta warisan dengan kewajiban atau beban kehidupan yang harus ditanggung atau

\footnotetext{
${ }^{5}$ Departemen Pendidikan dan Kebudayaan RI, Kamus Besar Bahasa Indonesia, (Cet. X; Jakarta: Balai Pustaka, 1999), h. 518.

${ }^{6}$ Sarlito Wirawan Sarwono, Psikologi Sosial Psikologi Kelompok dan Psikologi Terapan (Jakarta: Balai Pustaka, 1999), h. 129.

${ }^{7}$ Carl Joachim Friedrich, Filsafat Hukum...., h. 24.

${ }^{8}$ Munir Fuady, Dinamika Teori Hukum (Bogor: Ghalia Indonesia, 2010), h. 93.
} 


\section{Tahkim}

Vol. XIV, No. 1, Juni 2018

ditunaikannya di antara para ahli waris. ${ }^{9}$ Karena itu, arti keadilan dalam hukum waris Islam bukan diukur dari kesamaan tingkatan antara ahli waris, tetapi ditentukan berdasarkan besar kecilnya beban atau tanggung jawab yang diembankan kepada mereka, ditinjau dari keumuman keadaan atau kehidupan manusia. Keadaan inilah yang disebut Aristoteles dengan keadilan distributif.

Teori keadilan ini jika dikaitkan dengan tema yang penulis teliti yaitu penulis akan melihat apakah penundaan pembagian warisan yang dilakukan masyarakat muslim Kota Langsa akan mengakibatkan ketidakadilan dalam bagian hak yang seharusnya diterima tiap-tiap ahli waris yang ada, atau penundaan warisan tersebut tidak berpengaruh pada jumlah atau bagian hak waris yang seharusnya diterima oleh ahli waris.

Ketiga, penulis menggunakan teori maqa id syari'ah. Maqa id syari'ah terdiri dari dua suku kata, maqa id yang merupakan bentuk jamak dari kata maq ad yang berarti tujuan, dan kata al-syari'ah yang sering dipahami dalam arti hukum Islam, jadi istilah maqa id syari'ah berarti tujuan-tujuan syari'at. ${ }^{10}$ Dalam ilmu $u$ ul fiqh, bahasan maqa id syari'ah bertujuan untuk mengetahui tujuan-tujuan yang hendak dicapai oleh perumusnya dalam mensyariatkan hukum. Tujuan hukum ini merupakan salah satu faktor penting dalam menetapkan hukum Islam yang ditetapkan melalui ijtihad. ${ }^{11}$ Setelah memahami defenisinya maka kita nantinya akan melihat apakah pembagian waris di Kota Langsa ini telah sesuai dengan tujuan hukum Islam yang telah melalui proses ijtihad yang luar biasa. Ulama $u$ ul fiqh sepakat menyatakan bahwa pada setiap hukum itu terkandung kemaslahatan bagi hamba Allah, baik kemaslahatan yang bersifat duniawi maupun ukhrawi. ${ }^{12}$

Dari ketiga teori di atas peneliti ingin melihat apakah pelaksanaan pembagian waris di Kota Langsa telah sejalan dengan teori yang ada, atau malah membantah teori tersebut. Untuk itu pendalaman materi waris yang penulis fokuskan pada penundaannya, nantinya apakah berimplikasi pada pembagian waris, atau malah ingin menciptakan maslahat (sesuai dengan tujuan maqa id syariah).

\section{Bentuk Praktik Penyegeraan Pembagian Warisan pada Masyarakat Muslim di Kota Langsa}

Dalam pelaksanaan pembagian warisan pada masyarakat muslim di Kota Langsa, terdapat beberapa cara yang dilakukan masyarakat dalam menyelesaikan permasalahan pembagian warisan. Dari hasil wawancara dan observasi yang penulis lakukan, terdapat 3 cara yang dilakukan masyarakat muslim di kota Langsa dalam menyelesaikan permasalahan pembagian harta warisan tersebut, yaitu dengan cara musyawarah atau kekeluargaan baik melibatkan keluarga saja maupunpun melibatkan perangkat desa, dan cara terakhir yaitu melalui Mahkamah Syar'iyah Langsa.

\footnotetext{
${ }^{9}$ Ahmad Zahari, Tiga Versi Hukum Kewarisan Islam: Syafi'i, Hazairin dan KHI (Pontianak: Romeo Grafika, 2003), h. 25.

${ }^{10}$ Al-Ghazali, Al-Mus a fa (Beirut: Dāar Ihya Turats Al-Arabi, 1997), h. 481.

${ }^{11}$ Al-Youbi, Maqashid Syariah wa Alaqatuha bi Al-Adilah Al-Syar'iyyah (Riyadh: Daaar Ibnu Jauzi, 2008), h. 44.

${ }^{12}$ Al-Syatibi, Al Muwafaqaat fi U ul al-Syari'ah (Beirut: Dār al-Kutub al-Ilmiyah, 2007), h. 15.
} 


\section{Tahkim}

Vol. XIV, No. 1, Juni 2018

\section{a. Pembagian Warisan dengan cara Kekeluargaan}

Banyak masyarakat Muslim di Kota Langsa yang menempuh cara pembagian warisan secara kekeluargaan. Pembagian warisan dengan cara ini biasanya lebih mudah dan lebih cepat prosesnya. Ada masyarakat yang tetap membagi hak masing-masing sesuai bagian-bagian dalam waris Islam, ada juga yang membagi rata sesuai kesepakatan bersama.

Salah satu Ulama Kota Langsa yang penulis wawancarai menyampaikan bahwa di desanya pelaksanaan pembagian warisan lebih banyak bersifat kekeluargaan. Namun ada juga yang melibatkan perangkat desa. Jika pembagian harta warisan itu melibatkan perangkat desa, maka pelaksanaan pembagian warisan tersebut disesuaikan dengan hukum Islam. Jika pelaksanaan pembagian harta warisan tersebut hanya melibatkan keluarga saja atau bersifat kekeluargaan, maka tidak diperlukan pengukuran tanah atau perhitungan jumlah harta warisan. Contohnya; pewaris meninggalkan 3 orang anak dan harta warisan berupa tanah yang terletak di tiga lokasi, maka tidak perlu adanya pengukuran. Masing-masing ahli waris mendapatkan tanah. Tapi jika pembagian warisan ini melibatkan perangkat desa, maka harus dilakukan pengukuran terlebih dahulu. Sampai saat ini pembagian warisan di desanya belum ada yang melibatkan Mahkamah Syar'iyah. Pembagian warisan selesai di desa saja. ${ }^{13}$

Penulis juga mewawancarai salah satu Lurah di Kecamatan Langsa Baro. Pak Hasballah mengatakan bahwa ada dua cara pelaksanaan pembagian warisan di desanya, pertama yaitu cara sesuai dengan hukum Islam dan yang kedua adalah dengan cara kesepakatan antara ahli waris. Jika pelaksanaan pembagian warisan itu berdasarkan kesepakatan, berarti harta warisan tersebut dibagi sama. Jika pelaksanaan pembagian warisan itu berdasarkan hukum Islam, maka pembagian warisan itu dilakukan dengan pembagian dua banding satu, dua bagian untuk anak laki-laki dan satu bagian untuk anak perempuan. Jika pelaksanaan pembagian warisan itu dengan cara kesepakatan, maka ahli waris akan melakukan musyawarah bersama dengan perangkat desa. ${ }^{14}$

Selanjutnya menurut salah satu Lurah di Kecamatan Langsa Kota, bahwa di desanya pelaksanaan pembagian warisan dilakukan dengan dua cara, yaitu dengan cara kekeluargaan dan dengan melibatkan perangkat desa. Namun pada umumnya pelaksanaan pembagian warisan tersebut dilakukan dengan kekeluargaan tanpa melibatkan perangkat desa. Jika ada masalah dalam pembagian warisan tersebut, masalah tersebut juga tidak melibatkan Mahkamah Syar'iyah, semua akan diselesaikan di desa. ${ }^{15}$

\section{b. Pembagian Warisan melalui Mahkamah Syar'iyah}

Berdasarkan hasil observasi penulis selama beberapa tahun ini, banyak juga masyarakat di Kota Langsa yang memilih menyelesaikan masalah warisan di Mahkamah Syari'iyah Langsa. Masyarakat Kota Langsa yang melibatkan Mahkamah Syar'iyah Langsa, tidak hanya mendaftarkan kasus-kasus warisan yang rumit saja,

${ }^{13}$ Tgk. Ridwan, S.Pd, Ulama Kota Langsa, wawancara di Kantor Permusyawaratan Ulama Kota Langsa, 1 Februari 2018.

${ }^{14}$ Hasballah, Geuchik Desa Alue Dua Kecamatan Langsa Baro Kota Langsa, wawancara di Alue Dua 26 Januari 2018.

${ }^{15}$ Geuchik Desa Tualang Tengoh Kecamatan Langsa Kota, Kota Langsa, wawancara di Desa Tualang Tengoh 12 Februari 2018. 


\section{Tahkim}

Vol. XIV, No. 1, Juni 2018

bahkan untuk sekedar penetapan ahli waris yang berhak pun mereka selesaikan melalui Mahkamah Syar'iyah Langsa.

Menurut salah satu pegawai di Mahkamah Syar'iyah Langsa, bahwa banyak kasus warisan yang masuk ke Mahkamah Syar'iyah Langsa. Baik kasus tersebut berupa penetapan ahli waris, harta bersama maupun warisan yang bermasalah seperti harta warisan dikuasai salah satu pihak. Selanjutnya penulis disarankan untuk melihat langsung putusan-putusan mengenai kasus warisan tersebut di website Mahkamah Syar'iyah. ${ }^{16}$ Menurut hasil pantauan yang penulis lihat di website resmi Mahkamah Syar'iyah Langsa, mulai dari tahun 2011 sampai tahun 2017 perkara mengenai waris Islam yang sudah putus mencapai 42 kasus.

\section{Bentuk Praktik Penundaan Pembagian Warisan Segera pada Masyarakat Muslim di kota Langsa}

Tunda atau menunda dalam Kamus Besar Bahasa Indonesia, berarti menghentikan dan akan dilangsungkan lain kali (lain waktu); mengundurkan waktu pelaksanaan; menangguhkan. Sedangkan penundaan ialah proses, cara, perbuatan menunda. Mengenai penundaan pembagian warisan, yang dimaksud dari penundaan dan keharusan membagikan harta warisan penulis rangkum dari wawancara Pak Gamal Achyar, Lc, M.Sh seorang pakar atau ahli tentang kewarisan dalam Islam serta penulis buku Panduan Praktis Pembagian Harta Warisan dalam Islam. Mengenai dalil tentang keharusan menyegerakan membagikan harta warisan, pak Gamal mengatakan bahwa memang tidak ada satupun dalil yang menyatakan harta warisan tersebut harus dibagikan pada hari sekian tanggal sekian. Tetapi secara tidak langsung, pembagian harta warisan ini harus disegerakan. Karena kalau tidak disegerakan tentu akan banyak terjadi penyimpangan-penyimpangan dalam permasalahan harta warisan. ${ }^{17}$

Mengenai batas waktu pembagian warisan yang sudah dikatakan penundaan, pak Gamal menambahkan, bahwa biasanya orang membagikan warisan itu ketika berkumpul semua ahli waris. Misalkan pada hari ketujuh, hari keempat puluh, atupun hari keseratus. Pada saat itu biasanya pembagian harta warisan dilakukan. Di atas 100 hari itu sudah dianggap penundaan dan bahkan ada yang dikatakan sampai masa kadarluasa. Masa kadarluasa itu jika sudah sampai waktu 30 tahun ke atas, kalaupun ada pengajuan ke pengadilan yang masalah warisannya yang sudah tiga puluh tahun keatas tidak pernah dibahas, itu dianggap permasalahan yang sudah kadarluasa. ${ }^{18}$

Berdasarkan hasil observasi dan wawancara yang penulis lakukan, banyak masyarakat muslim di Kota Langsa yang menunda-nunda membagikan harta warisan. Kasus pertama terjadi pada keluarga seperti Devi Armayani. Beliau merupakan salah satu ahli waris dari ayahnya yang sudah meninggal sejak tahun 2001. Ayahnya meninggalkan ahli waris yaitu istri, seorang anak laki-laki dan dua orang anak perempuan serta harta warisan berupa dua buah rumah yang terletak pada satu desa namun beda dusun. Rumah yang pertama merupakan warisan bawaan dari pewaris yang

\footnotetext{
${ }^{16}$ Pegawai Mahkamah Syar'iyah Langsa, wawancara di Kantor Mahkamah Syar'iyah Langsa, 1 Februari 2018.

${ }^{17}$ Gamal Achyar, wawancara di IAIN Langsa dalam acara "Training Of Trainer (TOT) Ilmu Mawaris untuk Imam Gampong, Dosen dan Mahasiswa di Kota Langsa”, 21 November 2017.

${ }^{18}$ Gamal Achyar, wawancara di IAIN Langsa dalam acara "Training Of Trainer (TOT) Ilmu Mawaris untuk Imam Gampong, Dosen dan Mahasiswa di Kota Langsa”, 21 November 2017.
} 


\section{Tahkim}

Vol. XIV, No. 1, Juni 2018

diperoleh dari peninggalan orang tua pewaris. Kemudian rumah yang kedua merupakan rumah yang dibangun oleh pewaris di atas tanah warisan milik istri pewaris. Anak dan istri pewaris tinggal di rumah kedua, sedangkan rumah pertama disewakan sejak tahun 2011. Karena sebelum tahun 2011 rumah tersebut dikuasai oleh saudara pewaris. Kemudian pada tahun 2015 anak pertama pewaris (Devi) menempati rumah pertama tersebut bersama suaminya. Sedangkan istri pewaris beserta dua anak pewaris lainnya menempati rumah kedua. Selama dua tahun Devi menempati rumah tersebut, sering terjadi keributan. Anak laki-laki pewaris sering menuntut bagian warisannya dan sering memaksa agar rumah pertama itu dijual agar ia bisa mendapatkan haknya. Sampai saat ini, Januari 2018 rumah pertama tersebut belum dijual dan disewakan pada orang lain. Hasil dari sewa tersebut digunakan istri pewaris untuk biaya tambahan dalam memenuhi kebutuhan keluarga. ${ }^{19}$

Menurut penulis, seharusnya pembagian harta warisan dalam kasus Devi harus segera dibagikan. Setidaknya ditetapkan dahulu siapa saja ahli waris dan berapa bagian warisannya, selanjutnya bisa dilakukan kesepakatan apakah rumah tersebut dijual atau dipakai bersama sampai semua ahli waris menikah. Agar tidak terjadi keributan dan perbedaan pendapat dikemudian hari.

Kasus kedua, ditemukan adanya penundaan pembagian waris seperti keluarga Rosnen Daulay. Ayahnya meninggal sejak tahun 2000 sedangkan ibunya meninggal tahun 2012. Namun sampai saat ini pembagian warisan tersebut belum dilaksanakan. Harta warisan yang ditinggalkan berupa tanah yang luas dan beberapa petak tambak ikan. Beberapa ahli waris sudah membangun rumah di atas tanah tersebut, sedangkan ahli waris yang lain belum mengambil tanah karena belum dilakukan pembagian. Pada akhirnya mereka sepakat, bahwa ahli waris yang belum membangun rumah dan mengambil bagian warisannya dapat memilih tanah yang masih tersisa. Pada awalnya tidak terjadi keributan dalam penundaan ini. Namun pada akhirnya dampak dari penundaan ini terlihat jelas. Tepat disebelah rumah para ahli waris terdapat sebuah masjid besar. Sejak masjid itu diluaskan, parit besar disebelah tanah milik para ahli waris dihilangkan dan ditimbun oleh panitia masjid. Kemudian parit dibelakang tanah para ahli waris yang terhubung dengan parit dibelakang masjid yang menyatu langsung dengan parit besar, telah ditimbun dan ditutup oleh panitia masjid sehingga setiap musim hujan hanya rumah para ahli waris saja yang kebanjiran karena parit sudah ditutup. Para ahli waris sudah sering meminta agar dibuatkan parit, namun panitia masjid menolak. Pada akhirnya, Februari 2018 saat para ahli waris ingin mengukur seluruh tanah dan ingin membagi rata diantara para ahli waris, barulah ditemukan bahwa sertifikan tanah milik masjid tersebut ada pada salah satu ahli waris. Di dalam surat tersebut dapat disimpulkan bahwa ternyata tanah para ahli waris sudah dikuasai panitia masjid. Karena perluasan masjid tersebut banyak memakan tanah dari bagian ahli waris. Panitia masjid telah menimbun parit dan mengambil bagian tanah yang seharusnya menjadi bagian dari ahli waris. Setelah salah satu ahli waris menjumpai kepala desa dan memperlihatkan bukti surat tanah tersebut, kepala desa terkejut dan tidak mengetahui bahwa surat tanah masjid tersebut ternyata ada pada ahli waris. Kemudian salah satu ahli waris mengancam kepala desa, apabila panitia masjid tidak

${ }^{19}$ Devi Armayani, salah satu warga Desa Sukarejo Kecamatan Langsa Timur, wawancara 20 November 2017. 


\section{Tahkím}

Vol. XIV, No. 1, Juni 2018

membuatkan parit dibelakang masjid, maka para ahli waris akan membawa kasus ini ke Mahkamah Syar'iyah. ${ }^{20}$

Menurut penulis, seharusnya pembagian warisan dalam keluarga Rosnen harus segera diselesaikan dengan melibatkan perangkat desa, agar terhindar dari perbedaan pendapat yang muncul kemudian. Selanjutnya mengenai tanah warisan yang digunakan panitia masjid untuk perluasan masjid, sebaiknya para ahli waris duduk bersama perangkat desa dan imam kampung untuk membahas permasalahan ini dan mencari solusi agar tidak ada pihak yang dirugikan dan kasus ini tidak sampai ke Mahkamah Syar'iyah.

Kasus ketiga, terjadi pada keluarga Nur'aini yang beralamatkan di Desa Alue Dua. Sebelum kedua orang tua dari suaminya meninggal, semua anak-anak pewaris sudah mendapatkan tanah sebagai hibah dari orang tua mereka. Semua tanah dibagi rata. Kemudian setelah ayah ahli waris meninggal, rumah peninggalan orang tua ahli waris yang dibangun diatas tanah bagian suami Nur'aini Daulay (anak pewaris) dikuasai oleh abang seibu dari suami Nur'aini. Sedangkan istri pewaris (ibu dari ahli waris) tinggal bersama ahli waris yang lain (kakak ipar Nur'aini). Kemudian salah satu ahli waris (suami dari Nur'aini) meninggal dan memiliki 2 anak perempuan dan seorang anak laki-laki. Bagian warisan alm suami Nur'aini masih dikuasai ahli waris yang lain. Kemudian setelah istri pewaris (ibu dari ahli waris) meninggal, barulah terjadi masalah dalam pembagian warisan. Anak pertama dari pewaris (abang seibu dari suami Nur'aini Daulay), ingin menguasai seluruh harta peninggalan warisan baik harta itu berupa rumah peninggalan orang tua ahli waris maupun tanah bagian dari alm suami Nur'aini daulay. abang seibu dari almarhum suami Nur'aini Daulay menjual secara paksa tanah beserta rumah tersebut tanpa seizin ahli waris dari suami Nur'aini daulay. Dengan mengancam ahli waris yang lain dan beberapa perangkat desa, akhirnya tanah dan rumah tersebut berhasil dijual. Hasil penjualan tersebut mereka bagi rata tanpa memberikan serupiahpun kepada Nur'aini dan anak-anaknya. Seharusnya Nur'aini dan anak-anaknya medapatkan jumlah uang dari penjualan tanah bagian warisan suaminya. Dalam kasus ini, bagian warisan yang seharusnya diterima keluarga Nur' aini menjadi hilang akibat dikuasi abang dan kakak dari suami Nur'aini. Namun akhirnya, ada salah satu kakak dari suami Nur'aini yang dengan ikhlas menukar sebuah rumah dan tanah dengan uang sedikit dan memberikan rumah dan tanah miliknya kepada anak-anak dari Nur'aini karena beliau kasian melihat hak warisan yang seharusnya diterima Nu'aini dan anak-anaknya dikuasai abang dari suami Nu'aini. ${ }^{21}$

Selanjutnya kasus keempat, masalah warisan yang terjadi dalam keluarga Sayuti. Kasus ini sudah sampai ke jalur hukum dimana melibatkan Mahkamah Syar'iyyah sebagai penyelesai perkara antara Sayuti dan adiknya melawan paman dan bibinya. Peneliti melihat langsung saat Sayuti dan adiknya menemui pengacara dan menceritakan masalah warisan yang seharusnya diterima oleh almarhum ayahnya. Dan peneliti sempat beberapa kali mengikuti sidang antara Sayuti dan adiknya yang didampingi pengacara melawan paman dan bibinya sendiri. Peneliti akan menceritakan

${ }^{20}$ Rosnen Daulay, warga Desa Alue Dua Kecamatan Langsa Baro Kota Langsa, wawancara di Alue Dua 26 Januari s/d10 Februari 2018.

${ }^{21}$ Nur'aini Daulay, wawancara di rumahnya Desa Alue Dua, Kecamatan Langsa Baro Kota Langsa pada hari Rabu tanggal 6 September 2017 pukul 16.00 WIB. 


\section{Tahkím}

Vol. XIV, No. 1, Juni 2018

sedikit kronologi yang peneliti ambil dari surat gugatan Nomor: 0133/Pdt.G/2017/MSLgs tertanggal 10 Mei 2017.

Sayuti dan Desi ingin meminta hak warisan yang seharusnya menjadi milik alm ayah mereka, karena ayah Sayuti masih hidup ketika kedua pewaris meninggal dunia. Namun, Paman dari Sayuti ingin menguasai harta warisan itu dan tidak memberikan bagian warisan milik alm ayah Sayuti kepada Sayuti dan Desi. Paman dari Sayuti setelah menguasai surat warisan asli tersebut melakukan tindakan yang sangat tidak berkeprimanusiaan, yaitu dengan cara memerintahkan orang-orang suruhannya secara arogan untuk melakukan pembongkaran paksa terhadap usaha door smear yang didirikan Sayuti di atas tanah peninggalan ayahnya.

Paman dari sayuti tanpa perikeadilan menebang kurang lebih 50 pohon durian siap panen yang ada di tanah alm ayah Sayuti dan kemudian batangnya dijual ke kilang kayu. Kemudian paman Sayuti mengusir Sayuti, Desi dan Ibu mereka dari tanah yang ditinggalkan ayah Sayuti berdasarkan surat warisan tahun 1998. Selama ini Sayuti dan Desi telah penuh itikad baik untuk menyelesaikan permasalahan tersebut telah melakukan upaya mediasi dengan pamannya di Kantor Pertahanan Kota Langsa akan tetapi tidak dicapai kesepakatan sebagaimana tertuang dalam berita acara mediasi No. 02/BAM/11.03.400/2017 tanggal 10 Januari 2017.

Dari surat gugatan yang diajukan oleh penggugat ini, peneliti melihat bahwa semua persoalan yang terjadi dalam keluarga Sayuti ini berawal dari adanya penundaan pembagian harta warisan yang dilakukan oleh almarhumah nenek Sayuti sejak Kakek Sayuti meninggal. Kasus ini dalam Mahkamah Syar'iyah Langsa dimenangkan oleh keluarga Sayuti, namun kini kasus ini naik banding ke Mahkamah Syar'iyah Provinsi.

Kasus kelima, terjadi pada keluarga pak Abu di Lorong D Kampung Paya Bujuk Seulemak. Tgk. Ridwan, salah satu ulama di Kota Langsa yang penulis wawancarai di Kantor Permusyawaratan Ulama Kota Langsa, beliau menceritakan bahwa ada seorang kepala keluarga yang sudah meninggal 5 tahun yang lalu, kemudian istrinya juga meninggal 5 tahun kemudian. Sampai saat ini harta warisan belum dibagikan. Pewaris meninggalkan 12 anak dari dua istri. Pada saat semua ahli waris masih hidup, harta warisan tetap tidak dibagikan. Kemudian ada beberapa ahli waris yang meninggal dunia dan memiliki anak. Menurut tgk Ridwan, hal ini sudah menimbulkan dosa karena ahli waris yang sudah meninggal tersebut tidak bisa merasakan harta warisan yang seharusnya menjadi miliknya. Hal ini terjadi karena penundaan pembagian warisan yang dilakukan para ahli waris. Kemudian beberapa ahli waris menjadikan "patah tuetue" sebagai alasan agar anak dari ahli waris yang sudah meninggal sebelum harta warisan itu dibagikan, menjadi hilang bagiannya. Menurut tgk. Ridwan yang dinamakan "patah tuetue" itu adalah ketika ahli waris meninggal sebelum meninggalnya pewaris. Sampai saat ini masalah warisan ini belum selesai dan warisan belum dibagikan. Ketika penulis mencoba meminta alamat dan mewawancara langsung keluarga ini, Tgk Ridwan melarang dan mengatakan bahwa keluarga tersebut emosional dan akan berdampak negatif jika penulis mewawancarai langsung. ${ }^{22}$

Menurut penulis, seharusnya masalah warisan ini melibatkan Mahkamah Syar'iyah agar permasalahan warisan ini dapat diselesaikan, karena pihak desa sudah

${ }^{22}$ Tgk. Ridwan, S.Pd, Ulama Kota Langsa, wawancara di Kantor Permusyawaratan Ulama Kota Langsa, 1 Februari 2018 


\section{Tahkim}

Vol. XIV, No. 1, Juni 2018

menyerah dalam menyelesaikan pembagian warisan ini. Jika sudah melibatkan Mahkamah syar'iyah, maka permasalahan dapat diselesaikan dan para ahli waris dapat menerima bagian warisan yang seharusnya menjadi milik mereka.

Kasus keenam, yaitu terjadi pada keluarga Zubaidah binti Tgk. Ali Basyah. Beliau telah membawa permasalah warisan keluarganya ke Mahkamah Syar'iyah Langsa berdasarkan surat putusan yang penulis baca nomor Nomor 0278/Pdt.G/2015/MS Lgs. Setelah meninggalnya Ayah dan Ibu Kandung dari Zubaidah, ada meninggalkan banyak harta warisan berupa berupa tanah dan sawah yang dikuasai oleh seluruh ahli waris, namun sebagian besar masih dikuasai oleh saudara kandung Zubaidah, yaitu Asnah dan yang lainnya. Tanah tanah dan rumah tersebut diatas belum di bagi dan belum dibuatkan berupa Akte Waris kepada masing-masing ahli waris demikian juga terhadap sebahagian tanah yang tercantum dalam Akta Pembagian Hak / Bersama Nomor. 157 / 2011 seluas: $6120 \mathrm{~m}^{2}$ sampai saat ini belum dibagi sebagaimana mestinya.

Sebelum perkara ini diajukan melalui Mahkamah Syari'yah Langsa untuk diselesaikan tentang harta warisan Ayah Kandung Zubaidah, terlebih dahulu diselesaikan melalui Geuchik Gampong Seunebok Antara, Tuha Peut Gampong dan Imum Gampong yang telah berupaya menyelesaikan dengan jalan musyawarah kekeluargaan yang diselenggarakan di rumah Zubaidah Binti Ali Basyah, akan tetapi upaya tersebut tidak berhasil dikarenakan salah satu keluarga Alm. Tgk.Ali Basyah tidak mau menerimanya sebagaimana dimuat dalam Berita Acara Penyelesaian Masalah Sengketa Tanah Warisan, maka untuk menghindari hal hal yang tidak diinginkan dalam hubungan keluarga, Zubaidah meneruskan perkara ini melalui Mahkamah Syari'yah Langsa".

Kasus ketujuh terjadi pada keluarga Pak Umam. Pada keluarga beliau, mereka akan berusaha membuat kesepakatan bahwa harta warisan tersebut akan dijadikan sedekah jariyah untuk lembaga pendidikan ataupun untuk lembaga keagamaan. Mereka sekeluarga sedang berusaha menyatukan persepsi apakah mereka menjadikan harta warisan tersebut sebagai sedekah jariyah atau ditunda dulu sampai cucu-cucu pewaris selesai semua kebutuhannya. Setelah semua selesai maka mereka akan berdiskusi kembali, tetap dilaksanakan pembagian warisan ataupun dijadikan sedekah jariyah. Selama ini, hasil dari harta warisan tersebut tetap dibagi sesuai kesepakatan yang telah mereka buat. Menurut pak Umam, tidak ada terjadi masalah dalam penundaan ini. Sampai saat ini tidak terjadi perbedaan pendapat dalam bagian warisan tersebut. ${ }^{23}$

Menurut penulis, jika pembagian warisan ini tidak segera dilaksanakan maka tidak menutup kemungkinan akan terjadi perbedaan pendapat dan menimbulkan masalah diantara ahli waris kedepannya. Apalagi jika ada ahli waris yang meninggal, maka diantara anak dari ahli waris dan ahli waris yang lain kemungkinan bisa menimbulkan masalah.

Kasus kedelapan terjadi pada keluarga Ayu Rahmi. Sejak ayahnya meniggal dunia, sampai saat ini harta warisan peninggalan ayahnya belum dibagikan. Pewaris meninggalkan sebuah rumah terletak di Desa Paya Bujuk. Ahli waris terdiri dari istri dan 7 orang anak, salah satunya Ayu. Selama ini, rumah tersebut ditempati oleh istri dan

\footnotetext{
${ }^{23}$ Umam, wawancara di IAIN Langsa, warga Paya Bujuk Kecamatan Langsa Baro Kota Langsa pada hari Senin, tanggal 12 Februari 2018.
} 


\section{Tahkim}

Vol. XIV, No. 1, Juni 2018

sebagian anak dari pewaris, karena anak yang lain berada di luar kota. Dalam keluarga ini, penundaan pembagian warisan dilakukan karena masih hidupnya istri pewaris atau ibu dari ahli waris sehingga sampai saat ini belum terjadi perbedaan pendapat dan belum terdapat masalah dalam penundaan ini. Menurut Ayu, rumah tersebut sekarang sudah banyak direnovasi, dana diperoleh dari salah satu ahli waris, walaupun ahli waris tersebut tidak tinggal di rumah itu. Namun mereka sepakat, suatu saat nanti biarlah ahli waris yang memberikan dana renovasi tersebut yang akan tinggal di rumah itu. ${ }^{24}$

Kasus kesembilan terjadi pada keluarga alm Pak Usman (Wak Hek). Orang tua dari alm Pak Usman mempunyai banyak harta peninggalan berupa tanah dan harta yang lainnya. Setelah orang tuanya meninggal, tidak ada pembagian warisan yang dilakukan sampai belasan tahun. Sampai pada akhirnya Pak Usman selaku ahli waris tersebut meninggal, sedangkan ia belum menerima jatah warisan yang seharusnya menjadi miliknya. Setelah pak Usman meninggal, barulah dilakukan pembagian harta warisan. Dalam kasus ini, telah terjadi penundaan pembagian warisan yang telah dilakukan oleh pak Usman dan keluarganya.

Selanjutnya penulis menemukan 4 kasus lagi yang masalah warisannya sampai ke Mahkamah Syar'iyah, setelah penulis amati kasus tersebut bermula dari penundaan pembagian warisan yang dilakukan para ahli waris. Kasus tersebut terdaftar dalam perkara nomor: 39/Pdt.G/2013/MS-LGS, nomor: 206/Pdt.G/2015/MS Lgs, nomor: 292/Pdt.G/2013/MS-LGS, nomor: 307/Pdt.G/2013/MS-LGS.

Dari 42 kasus yang masuk dalam Mahkamah Syar'iyah Langsa, terdapat 36 kasus diantaranya berupa penetapan ahli waris dan 6 kasus lainnya berupa konflik yang disebabkan dari penundaan pembagian warisan yang dilakukan oleh masyarakat. Dari 6 kasus penundaan pembagian warisan yang menimbulkan konflik tersebut, satu kasus yang selesai di Mahkamah Syar'iyah Langsa, namun perkara tersebut dilanjutkan banding ke Mahkamah Syar'iyah Aceh dan sampai saat ini masih dalam proses sidang. Kasus ini yaitu kasus yang terjadi pada keluarga Sayuti. Kemudian terdapat 1 kasus penundaan pembagian warisan yang dicabut oleh ahli waris sehingga kasus tersebut selanjutnya diselesaikan secara kekeluargaan antara ahli waris. Kemudian 4 kasus lainnya selesai di Mahkamah Syar'iyah Langsa.

Selanjutnya terdapat 7 masalah penundaan pembagian warisan yang tidak sampai ke Mahkamah, yaitu penundaan pembagian warisan yang terjadi pada keluarga Devi, Rosnen Daulay, Nur'aini Daulay, kawasan Tgk. Ridwan, Pak Umam, Ayu Rahmi dan keluarga alm Pak Usman. 7 kasus penundaan pembagian warisan tersebut 1 diantaranya selesai di desa. Terdapat 1 kasus yang sudah melibatkan perangkat desa tapi sampai saat ini masih terjadi konflik dan belum selesai sampai saat ini. Kemudian 5 kasus lainnya sampai saat ini belum melibatkan perangkat desa dan belum melaksanakan pembagian warisan.

Menurut penulis, tidak semua kasus yang berhubungan dengan pembagian harta warisan dapat diselesaikan di Desa, hanya kasus-kasus yang tidak terlalu rumit saja yang bisa diselesaikan di desa. Jika kasus itu sudah terlalu rumit dan menimbulkan banyak konflik dan perangkat desa tidak mampu untuk membantu menyelesaikan masalah tersebut, maka kasus akan dibawa dan didaftarkan ke Mahkamah Syar'iyah

${ }^{24}$ Ayu Rahmi, wawancara di rumahnya Desa Paya Bujuk, Kecamatan Langsa Baro Kota Langsa pada hari Kamis tanggal 7 September 2017. 


\section{Tahkím}

Vol. XIV, No. 1, Juni 2018

Langsa dan akan diselesaikan di Mahkamah Syar'iyah Langsa. Jika putusan Mahkamah Syar'iyah Langsa masih belum berkenan di hati para ahli waris, kasus akan dilanjutkan dengan melakukan banding ke Mahkamah Syar'iyah Aceh. Jadi, Perangkat desa dan Mahkamah Syar'iyah Langsa mempunyai peranan penting dalam menyelesaikan masalah warisan pada masyarakat muslim yang terjadi di Kota Langsa.

\section{Sebab-sebab Penundaan Pembagian Warisan pada Masyarakat Muslim di Kota Langsa}

Banyak masyarakat Muslim di Kota Langsa yang melakukan penundaan pembagian warisan. Mengenai faktor atau alasan dari penundaan pembagian warisan yang sering dilakukan masyarakat, pak Gamal Akhyar mengatakan bahwa ada dua macam penundaan yang dilakukan masyarakat kota Langsa. Pertama, penundaan pembagian warisan berdasarkan kesepakatan semua ahli waris, yaitu ketika ada pewaris meninggal dunia kemudian ada diantara ahli warisnya yang masih kecil, ataupun terjadi sebuah kesepakatan dari orang tuanya untuk tidak membagikan warisan, ataupun harta warisan itu berbentuk sebuah perusahaan yang apabila dibagikan maka perusahaan tersebut tidak dapat dijalankan. Kedua, penundaan pembagian warisan dilakukan karena lalainya para ahli waris, mereka menganggap tabu jika membahas persoalan warisan yang pada akkhirnya penundaan ini terjadi sampai puluhan tahun sehingga meimbulkan konflik. $^{25}$

Setelah penulis wawancara ternyata mempunyai beberapa faktor atau alasan mengapa penundaan itu sampai dilakukan. Dari semua hasil observasi dan wawancara, penulis akan memaparkan beberapa faktor tersebut yaitu sebagai berikut:

\section{a. Kesepakatan seluruh ahli waris}

Sebab pertama dilakukan penundaan pembagian warisan pada masyarakat muslim di Kota Langsa yaitu karena adanya kesepakatan semua ahli waris untuk menunda melakukan pembagian harta warisan.

Salah satu kasus yang berkaitan dengan sebab ini terjadi pada keluarga pak Umam. alasan keluarga pak Umam menunda membagikan harta warisan adalah karena mereka membuat kesepakatan bahwa harta warisan tersebut akan dijadikan sedekah jariyah untuk lembaga pendidikan ataupun untuk lembaga keagamaan. Mereka sekeluarga sedang berusaha menyatukan persepsi apakah mereka menjadikan harta warisan tersebut sebagai sedekah jariyah atau ditunda dulu sampai cucu-cucu pewaris selesai semua kebutuhannya. ${ }^{26}$

Menurut penulis, jika pembagian warisan ini tidak segera dilaksanakan maka tidak menutup kemungkinan akan terjadi perbedaan pendapat dan menimbulkan masalah diantara ahli waris kedepannya. Apalagi jika ada ahli waris yang meninggal, maka diantara anak dari ahli waris dan ahli waris yang lain kemungkinan bisa menimbulkan masalah.

\footnotetext{
${ }^{25}$ Gamal Achyar, wawancara di IAIN Langsa dalam acara "Training Of Trainer (TOT) Ilmu Mawaris untuk Imam Gampong, Dosen dan Mahasiswa di Kota Langsa”, 21 November 2017.

${ }^{26}$ Umam, wawancara di IAIN Langsa, warga Paya Bujuk Kecamatan Langsa Baro Kota Langsa pada hari Senin, tanggal 12 Februari 2018
} 


\section{Tahkím}

Vol. XIV, No. 1, Juni 2018

\section{b. Ahli waris banyak yang masih kecil atau belum waktunya mendapatkan warisan}

Sebab kedua dilakukan penundaan pembagian warisan pada masyarakat muslim di Kota Langsa yaitu yaitu karena ahli waris banyak yang masih kecil atau belum waktunya mendapatkan warisan.

Salah satu kasus yang berkaitan dengan faktor ini terjadi pada keluarga devi. Menurut Devi, alasan keluarganya menunda pembagian warisan yaitu karena terjadi kesepakatan antara ahli waris bahwa rumah yang merupakan harta warisan tersebut tidak akan dibagikan sebelum semua anak-anak dari pewaris menikah. Jika semua sudah menikah, maka rumah tersebut akan dijual. Kesepakatan ini dilakukan karena ada salah satu ahli waris yang boros dan ahli waris yang lain takut jika harta warisan ini akan habis. $^{27}$

Menurut penulis, seharusnya pembagian harta warisan dalam kasus Devi harus segera dibagikan. Setidaknya ditetapkan dahulu siapa saja ahli waris dan berapa bagian warisannya, selanjutnya bisa dilakukan kesepakatan apakah rumah tersebut dijual atau dipakai bersama sampai semua ahli waris menikah. Agar tidak terjadi keributan dan perbedaan pendapat dikemudian hari.

\section{c. Karena beberapa pihak ingin menguasai harta warisan sehingga ditundanya pembagian warisan itu}

Sebab ketiga dilakukan penundaan pembagian warisan pada masyarakat muslim di Kota Langsa yaitu yaitu karena beberapa pihak ingin menguasai harta warisan sehingga ditundanya pembagian warisan itu. Penulis akan memaparkan beberapa kasus yaitu:

Kasus pertama seperti pada keluarga Nur'aini. setelah kedua orang tua ahli waris meninggal, rumah peninggalan orang tua ahli waris yang dibangun diatas tanah bagian suami Nur'aini Daulay (anak pewaris) dikuasai oleh abang seibu dari suami Nur'aini. Beberapa tahun mereka tinggal di rumah tersebut, tidak dilakukan pembagian warisan hingga akhirnya abang seibu dari suami Nur'aini menjual paksa rumah beserta tanah milik alm suami Nur'aini yang seharusnya menjadi hak Nur'aini dan ketiga anaknya. ${ }^{28}$

Kasus kedua seperti pada keluarga Sayuti. Salah satu alasan keluarga Sayuti menunda pembagian waris ialah karena paman dari Sayuti ingin menguasai harta warisan dan tidak memberikan bagian warisan milik alm ayah Sayuti kepada Sayuti dan Desi. Beberapa toko yang disewakan, hasilnya dikuasai salah satu pihak tanpa membagikannya kepada yang lain.

Kasus ketiga terjadi pada keluarga pak Abu di Lorong D Kampung Paya Bujuk Seulemak. Pada saat semua ahli waris masih hidup, harta warisan tetap tidak dibagikan. Kemudian ada beberapa ahli waris yang meninggal dunia dan memiliki anak. Penundaan pembagian warisan dilakukan yaitu karena ada ahli waris yang ingin menguasai harta warisan. ${ }^{29}$

\footnotetext{
${ }^{27}$ Devi Armayani, salah satu warga Desa Sukarejo Kecamatan Langsa Timur, wawancara 20 November 2017.

${ }^{28}$ Nur'aini Daulay, wawancara di rumahnya Desa Alue Dua, Kecamatan Langsa Baro Kota Langsa pada hari Rabu tanggal 6 September 2017 pukul 16.00 WIB.

${ }^{29}$ Tgk. Ridwan, S.Pd, Ulama Kota Langsa, wawancara di Kantor Permusyawaratan Ulama Kota Langsa, 1 Februari 2018
} 


\section{Tahkím}

Vol. XIV, No. 1, Juni 2018

Menurut penulis, seharusnya masalah warisan ini melibatkan Mahkamah Syar'iyah agar permasalahan warisan ini dapat diselesaikan, karena pihak desa sudah menyerah dalam menyelesaikan pembagian warisan ini. Jika sudah melibatkan Mahkamah syar'iyah, maka permasalahan dapat diselesaikan dan para ahli waris dapat menerima bagian warisan yang seharusnya menjadi milik mereka.

Kasus keempat terjadi pada keluarga Zubaidah binti Tgk. Ali Basyah. Setelah meninggalnya Ayah dan Ibu Kandung dari Zubaidah, ada meninggalkan banyak harta warisan berupa berupa tanah dan sawah yang dikuasai oleh seluruh ahli waris, namun sebagian besar masih dikuasai oleh saudara kandung Zubaidah, yaitu Asnah dan yang lainnya.

Begitu juga alasan yang disampaikan oleh pak Hasbalah, bahwa ada salah satu pihak yang ingin menguasai harta warisan itu sehingga pihak yang lain tidak mendapatkan bagian dari warisan itu. Hal ini sering terjadi di Desa Alue Dua. ${ }^{30}$

\section{d. Sebagian besar masyarakat menganggap membahas masalah warisan setelah pewaris meninggal adalah tabu.}

Sebab keempat dilakukan penundaan pembagian warisan pada masyarakat muslim di Kota Langsa yaitu yaitu karena sebagian besar masyarakat menganggap membahas masalah warisan setelah pewaris meninggal adalah tabu.

Salah satu kasus yang berkaitan dengan faktor ini yaitu terjadi pada keluarga alm Pak Usman (Wak Hek). Setelah orang tuanya meninggal, tidak ada pembagian warisan yang dilakukan sampai belasan tahun. Penundaan pembagian warisan ini terjadi karena masih ada anggapan bahwa tabu atau pantang membahas masalah warisan dalam keluarga ini. Tidak ada satupun ahli waris yang membahas atau mempersoalan masalah warisan hingga akhirnya salah satu satu ahli waris (Pak Usman) meninggal dunia.

\section{e. Masih hidupnya salah satu ayah atau ibu pewaris}

Sebab kelima dilakukan penundaan pembagian warisan pada masyarakat muslim di Kota Langsa yaitu yaitu karena masih hidupnya salah satu ayah atau ibu pewaris. Penulis akan memaparkan beberapa kasus yaitu:

Kasus pertama terjadi pada keluarga Devi. Menurut Devi, alasan lain keluarganya menunda pembagian warisan yaitu karena istri pewaris (ibu kandung Devi) masih hidup, jika rumah tersebut disewakan tentu akan menjadi tambahan dana untuk kehidupan keluarga mereka. Jadi keluarga Devi menunda membagikan hata warisan. ${ }^{31}$

Kasus kedua seperti pada keluarga Rosnen Daulay, ditundanya pembagian harta warisan karena ketika alm ayah Rosnen meninggal, ibunya masih hidup. Selama 12 tahun tidak dilakukan pembagian harta warisan, namun sebagian ahli waris sudah membangun rumah diatas tanah warisan tersebut. Kemudian, sebagian besar ahli waris yang lain tinggal di luar kota dan mereka tidak terlalu memikirkan harta warisan tersebut. Pembagian warisan baru dilakukan setelah 6 tahun ibunya meninggal.

Menurut penulis, seharusnya pembagian warisan dalam keluarga Rosnen harus segera diselesaikan dengan melibatkan perangkat desa, agar terhindar dari perbedaan

${ }^{30}$ Hasballah, Geuchik Desa Alue Dua Kecamatan Langsa Baro Kota Langsa, wawancara di Alue Dua 26 Januari 2018.

31 Devi Armayani, salah satu warga Desa Sukarejo Kecamatan Langsa Timur, wawancara 20 November 2017. 


\section{Tahkím}

Vol. XIV, No. 1, Juni 2018

pendapat yang muncul kemudian. Selanjutnya mengenai tanah warisan yang digunakan panitia masjid untuk perluasan masjid, sebaiknya para ahli waris duduk bersama perangkat desa dan imam kampung untuk membahas permasalahan ini dan mencari solusi agar tidak ada pihak yang dirugikan dan kasus ini tidak sampai ke Mahkamah Syar'iyah.

Kasus ketiga seperti pada keluarga Sayuti. Salah satu alasan ditundanya pembagian warisan ada keluarga ayah dari Sayuti adalah karena ibu dari ayah Sayuti (nenek Sayuti) masih hidup hingga beberapa tahun kemudian setelah ibu dari ayah Sayuti (nenek Sayuti) sudah meninggal, barulah harta warisan itu diributkan pembagiannya.

Kasus keempat terjadi pada keluarga Ayu Rahmi. Sejak ayahnya meniggal dunia, sampai saat ini harta warisan peninggalan ayahnya belum dibagikan. Dalam keluarga ini, penundaan pembagian warisan dilakukan karena masih hidupnya istri pewaris atau ibu dari ahli waris sehingga sampai saat ini belum terjadi perbedaan pendapat dan belum terdapat masalah dalam penundaan ini.

\section{Dampak Penundaan Pembagian Warisan pada Masyarakat Muslim di Kota Langsa}

Setelah penulis mengobservasi dan mewawancarai beberapa tokoh masyarakat, penulis melihat begitu banyak dampak negatif yang ditimbulkan dari penundaan pembagian warisan yang dilakukan masyarakat Kota Langsa, sebagai berikut:

\section{a. Terjadi konflik diantara ahli waris, baik itu konflik ringan sampai konflik berat}

Menurut Gamal Achyar, penundaan pembagian warisan ini dapat menjadi sumber konflik, karena nantinya akan ada ahli waris tertentu yang menguasai harta warisan. Terlalu lama menunda pembagian warisan juga bisa merdampak pada berkas atau dokumen yang hilang, kemudian ada ahli waris yang meninggal. ${ }^{32}$

Dampak pertama yaitu terjadi konflik diantara ahli waris, baik itu konflik ringan sampai konflik berat. Penulis akan memaparkan contoh kasus yaitu: Tgk. Ridwan memaparkan mengenai dampak dari penundaan pembagian warisan yang dilakukan keluarga pak Abu. Menurut Tgk. Ridwan, penundaan pembagian warisan yang dilakukan masyarakat Kota Langsa berdampak negatif atau tidak baik. Seharusnya harta warisan harus dibagi langsung karna semua ahli waris masih hidup, namun sampai hari ini harta warisan tersebut belum dibagikan. Beberapa ahli waris sudah meninggal sebelum harta warisan itu sempat dibagikan, ahli waris yang meninggal tersebut memiliki anak. Menurut Tgk. Ridwan ini merupakan dosa. Kemudian pihak lain menjadikan ini sebagai alasan agar anak dari ahli waris yang sudah meninggal ini tidak mendapatkan bagian orangtuanya. Mereka mengatakan masalah ini termasuk dalam istilah patah tuetue. Jadi sekarang, ini masih menjadi sebuah permasalahan. Dampak yang paling parah dari kasus ini yaitu antara adik dan abang terjadi keributan dan

${ }^{32}$ Gamal Achyar, wawancara di IAIN Langsa dalam acara "Training Of Trainer (TOT) Ilmu Mawaris untuk Imam Gampong, Dosen dan Mahasiswa di Kota Langsa”, 21 November 2017. 


\section{Tahkim}

Vol. XIV, No. 1, Juni 2018

hampir terjadi pembacokan diantara keduanya. Harta warisan yang berupa rumah tua itu pun tidak boleh disewakan dan tidak boleh ditempati. ${ }^{33}$

Penulis juga menemukan banyak dampak negatif dari penundaan pembagian warisan yang terjadi dalam keluarga Sayuti seperti yang penulis temui dan pahami dari surat gugatan tersebut. Paman Sayuti mengalami perubahan secara sikap, ucapan, serta tindakan yang terlihat begitu hipokrit/munafik setelah menguasai surat faraidh asli yang sebelumnya dipegang oleh ibu kandung Sayuti dan Desi. Paman Sayuti telah menguasai surat warisan asli tersebut melakukan tindakan yang sangat tidak berkeprimanusiaan, yaitu dengan cara memerintahkan orang-orang suruhannya secara arogan untuk melakukan pembongkaran paksa terhadap usaha door smear yang didirikan Sayuti di atas tanah peninggalan ayahnya yaitu Ir. Hasballah (Alm). Paman Sayuti tanpa perikeadilan menebang kurang lebih 50 pohon durian siap panen yang ada di tanah Ir. Hasballah (Alm) dan kemudian batangnya dijual ke kilang kayu. Paman Sayuti tanpa perikemanusiaan/rasa iba mengusir Sayuti, Desi dan Ibu tiri/istri kedua Ir. Hasballah (alm) dari tanah yang ditinggalkan Ir. Hasballah (Alm) berdasarkan surat warisan tahun 1998. Dalam kurun waktu selama 18 tahun telah terjadi penjualan/pengutipan sewa terhadap tanah/took yang telah menjadi hak/milik masing-masing ahli waris berdasarkan surat pembagian harta warisan (faraidh) tertanggal 20 Oktober 1998.

\section{b. Adanya hak-hak ahli waris yang berkurang dari bagian yang seharusnya diterima}

Dampak kedua yaitu adanya hak-hak ahli waris yang berkurang dari bagian yang seharusnya diterima. Penulis akan memaparkan contoh kasus yaitu: Penulis melihat terjadi dampak negatif pada kasus warisan keluarga Rosnen Daulay yaitu beberapa ahli waris sudah membangun rumah di atas tanah tersebut, sedangkan ahli waris yang lain belum mengambil tanah karena belum dilakukan pembagian. Pada akhirnya mereka sepakat bahwa ahli waris yang belum membangun rumah dan mengambil bagian warisannya dapat memilih tanah yang masih tersisa. Pada awalnya tidak terjadi keributan dalam penundaan ini. Namun pada akhirnya dampak-dampak dari penundaan ini terlihat jelas. Tepat disebelah rumah para ahli waris terdapat sebuah masjid besar. Sejak masjid itu diluaskan, parit besar disebelah tanah milik para ahli waris dihilangkan dan ditimbun oleh panitia masjid. Kemudian parit dibelakang tanah para ahli waris yang terhubung dengan parit dibelakang masjid yang menyatu langsung dengan parit besar, telah ditimbun dan ditutup oleh panitia masjid sehingga setiap musim hujan hanya rumah para ahli waris saja yang kebanjiran karena parit sudah ditutup. Para ahli waris sudah sering meminta agar dibuatkan parit, namun panitia masjid menolak. Pada akhirnya, Februari 2018 saat para ahli waris ingin mengukur seluruh tanah dan ingin membagi rata diantara para ahli waris, barulah ditemukan bahwa sertifikan tanah milik masjid tersebut ada pada salah satu ahli waris. Di dalam surat tersebut dapat disimpulkan bahwa ternyata tanah para ahli waris sudah dikuasai panitia masjid. Karena perluasan masjid tersebut banyak memakan tanah dari bagian ahli waris. Panitia masjid telah menimbun parit dan mengambil bagian tanah yang seharusnya menjadi bagian dari ahli waris. Setelah salah satu ahli waris menjumpai kepala desa dan memperlihatkan bukti surat tanah tersebut, kepala desa terkejut dan tidak mengetahui bahwa surat tanah

${ }^{33}$ Tgk. Ridwan, S.Pd, Ulama Kota Langsa, wawancara di Kantor Permusyawaratan Ulama Kota Langsa, 1 Februari 2018. 


\section{Tahkim}

Vol. XIV, No. 1, Juni 2018

masjid tersebut ternyata ada pada ahli waris. Kemudian salah satu ahli waris mengancam kepala desa, apabila panitia masjid tidak membuatkan parit dibelakang masjid, maka para ahli waris akan membawa kasus ini ke Mahkamah Syar'iah. ${ }^{34}$

Selanjutnya penulis melihat terjadi dampak negatif pada kasus warisan Nur'aini Daulay. rumah peninggalan orang tua ahli waris yang dibangun diatas tanah bagian suami Nur'aini Daulay (anak pewaris) dikuasai oleh abang seibu dari suami Nur'aini. Sedangkan istri pewaris (ibu dari ahli waris) tinggal bersama ahli waris yang lain (kakak ipar Nur'aini). Kemudian salah satu ahli waris (suami dari Nur'aini) meninggal dan memiliki 2 anak perempuan dan seorang anak laki-laki. Bagian warisan alm suami Nur'aini masih dikuasai ahli waris yang lain. Kemudian setelah istri pewaris (ibu dari ahli waris) meninggal, barulah terjadi masalah dalam pembagian warisan. Anak pertama dari pewaris (abang seibu dari suami Nur'aini Daulay), ingin menguasai seluruh harta peninggalan warisan baik harta itu berupa rumah peninggalan orang tua ahli waris maupun tanah bagian dari alm suami Nur'aini daulay. abang seibu dari almarhum suami Nur'aini Daulay menjual secara paksa tanah beserta rumah tersebut tanpa seizin ahli waris dari suami Nur'aini daulay. Dengan mengancam ahli waris yang lain dan beberapa perangkat desa, akhirnya tanah dan rumah tersebut berhasil dijual. Hasil penjualan tersebut mereka bagi rata tanpa memberikan serupiahpun kepada Nur'aini dan anak-anaknya. Seharusnya Nur'aini dan anak-anaknya medapatkan jumlah uang dari penjualan tanah bagian warisan suaminya. Dalam kasus ini, bagian warisan yang seharusnya diterima keluarga Nur'aini menjadi hilang akibat dikuasi abang dan kakak dari suami Nur'aini. Namun akhirnya, ada salah satu kakak dari suami Nur'aini yang dengan ikhlas menukar sebuah rumah dan tanah dengan uang sedikit dan memberikan rumah dan tanah miliknya kepada anak-anak dari Nur'aini karena beliau kasian melihat hak warisan yang seharusnya diterima Nu'aini dan anak-anaknya dikuasai abang dari suami Nu'aini. ${ }^{35}$

\section{c. Adanya ahli waris yang tidak bisa merasakan harta warisan karena meninggal sebelum harta warisan itu sempat dibagikan;}

Dampak ketiga yaitu adanya ahli waris yang tidak bisa merasakan harta warisan karena meninggal sebelum harta warisan itu sempat dibagikan. Penulis akan memaparkan contoh kasus yaitu: Pak Hasballah memaparkan dampak dari penundaan pembagian warisan ini. Menurutnya, dampak negatif ini tidak dapat dipungkiri karena tidak semua ahli waris itu hidupnya senang dan punya uang. Semua ahli waris ingin harta warisan itu segera dibagikan. Contoh Wak Hek (Wak Usman), sampai beliau meninggal, tidak mendapatkan bagian warisannya. Kemudian pembagian warisan yang dilakukan ahki waris yang lain tidak sesuai. Karena perangkat desa tidak ikut dalam dalam pembagian tersebut. Banyak ahli waris yang ingin menguasai harta warisan itu. di Desa Alue Dua banyak ditemukan kasus seperti itu. Tidak ada penuntutan yang dilakukan oleh ahli waris yang lain, karena pihak yang lemah akan kalah. ${ }^{36}$

\footnotetext{
${ }^{34}$ Rosnen Daulay, warga Desa Alue Dua Kecamatan Langsa Baro Kota Langsa, wawancara di Alue Dua 26 Januari s/d10 Februari 2018.

${ }^{35}$ Nur'aini Daulay, wawancara di rumahnya Desa Alue Dua, Kecamatan Langsa Baro Kota Langsa pada hari Rabu tanggal 6 September 2017 pukul 16.00 WIB.

${ }^{36}$ Hasballah, Geuchik Desa Alue Dua Kecamatan Langsa Baro Kota Langsa, wawancara di Alue Dua 26 Januari 2018
} 


\section{Tahkim}

Vol. XIV, No. 1, Juni 2018

Selanjutnya penulis melihat dampak negatif yang terjadi pada keluarga alm Pak Usman (Wak Hek). Orang tua dari alm Pak Usman mempunyai banyak harta peninggalan berupa tanah dan harta yang lainnya. Setelah orang tuanya meninggal, tidak ada pembagian warisan yang dilakukan sampai belasan tahun. Sampai pada akhirnya Pak Usman selaku ahli waris tersebut meninggal, sedangkan ia belum menerima jatah warisan yang seharusnya menjadi miliknya. Setelah pak Usman meninggal, barulah dilakukan pembagian harta warisan. Dalam kasus ini, telah terjadi penundaan pembagian warisan yang telah dilakukan oleh pak Usman dan keluarganya.

Menurut penulis, dampak yang paling besar adalah, Pak Usman selaku ahli waris semasa hidupnya tidak bisa merasakan atau memiliki jatah warisan yang seharusnya jadi miliknya. Seharusnya setelah orang tua dari Pak Usman meninggal, pembagian warisan ini harus segera dilaksanakan untuk menghindari berbagai dampak yang bisa terjadi.

\section{d. Putusnya silaturahmi atau persaudaraan antara ahli waris karena perebutan harta warisan.}

Dampak keempat yaitu putusnya silaturahmi atau persaudaraan antara ahli waris karena perebutan harta warisan. Penulis akan memaparkan contoh kasus yaitu: Penulis melihat terjadi dampak negatif pada kasus warisan keluarga Zubaidah binti Tgk. Ali Basyah. Setelah meninggalnya Ayah dan Ibu Kandung dari Zubaidah, ada meninggalkan banyak harta warisan berupa berupa tanah dan sawah yang dikuasai oleh seluruh ahli waris, namun sebagian besar masih dikuasai oleh saudara kandung Zubaidah, yaitu Asnah dan yang lainnya. Tanah tanah dan rumah tersebut diatas belum di bagi dan belum dibuatkan berupa Akte Waris kepada masing-masing ahli waris demikian juga terhadap sebahagian tanah yang tercantum dalam Akta Pembagian Hak / Bersama Nomor. 157 / 2011 seluas: $6120 \mathrm{~m}^{2}$ sampai saat ini belum dibagi sebagaimana mestinya.

Setelah meninggal dunia Harta Peninggalan Almarhum Tgk.Ali Basyah sebagaimana disebut diatas sebagian besar masih dikuasai oleh Para Asnah dan lainnya. Tanah tanah dan rumah tersebut diatas belum di bagi dan belum dibuatkan berupa Akte Waris kepada masing-masing ahli waris demikian juga terhadap sebahagian tanah yang tercantum dalam Akta Pembagian Hak / Bersama Nomor. 157/2011 seluas: $6120 \mathrm{~m}^{2}$ sampai saat ini belum dibagi sebagaimana mestinya.

Dari paparan tersebut penulis melihat beberapa ahli waris menguasai harta warisan, sehingga ahli waris yang lain membawa kasus ini ke Mahkamah Syar'iyah karena tidak terjadi kesepakatan walaupun sudah melibatkan perangkat desa.

\section{e. Dampak positif}

Dampak kelima yaitu penundaan pembagian warisan berdampak positif. Penulis akan memaparkan contoh kasus yaitu: Penulis melihat terjadi dampak positif terjadi pada keluarga Ayu Rahmi. Selama ini, rumah tersebut ditempati oleh istri dan sebagian anak dari pewaris, karena anak yang lain berada di luar kota. Dalam keluarga ini, penundaan pembagian warisan dilakukan karena masih hidupnya istri pewaris atau ibu dari ahli waris sehingga sampai saat ini belum terjadi perbedaan pendapat dan belum terdapat masalah dalam penundaan ini. Menurut Ayu, rumah tersebut sekarang sudah banyak direnovasi, dana diperoleh dari salah satu ahli waris, walaupun ahli waris tersebut tidak tinggal di rumah itu. Namun mereka sepakat, suatu saat nanti biarlah ahli 


\section{Tahkím}

Vol. XIV, No. 1, Juni 2018

waris yang memberikan dana renovasi tersebut yang akan tinggal di rumah itu. Namun, tidak menutup kemungkinan pada waktu yang akan datang penundaan ini bisa berdampak negatif jika harta warisan tersebut tidak segera dibagikan.

\section{Pandangan MPU Kota Langsa tentang Penundaan Pembagian Warisan pada Masyarakat Muslim di Kota Langsa}

Majelis Permusyawaratan Ulama Kota Langsa yang penulis wawancarai memaparkan bahwa dosa hukumnya apabila menunda-nunda pembagian warisan, karna dalam Islam itu setelah meninggalnya salah satu dalam keluarganya maka harta warisan harus segera dibagikan. ${ }^{37}$ Tgk Ridwan menyampaikan bahwa di desanya pelaksanaan pembagian warisan lebih banyak bersifat kekeluargaan. Namun ada juga yang melibatkan perangkat desa. Jika pembagian harta warisan itu melibatkan perangkat desa, maka pelaksanaan pembagian warisan tersebut disesuaikan dengan hukum Islam. Jika pelaksanaan pembagian harta warisan tersebut hanya melibatkan keluarga saja atau bersifat kekeluargaan, maka tidak diperlukan pengukuran tanah atau perhitungan jumlah harta warisan.

Contohnya pewaris meninggalkan 3 orang anak dan harta warisan berupa tanah yang terletak di tiga lokasi, maka tidak perlu adanya pengukuran. Masing-masing ahli waris mendapatkan tanah. Tapi jika pembagian warisan ini melibatkan perangkat desa, maka harus dilakukan pengukuran terlebih dahulu. Sampai saat ini pembagian warisan di desanya belum ada yang melibatkan Mahkamah Syar'iyah. Pembagian warisan selesai di Desa saja. ${ }^{38}$

Tgk Murdani bin Muhammad mengatakan bahwa terhadap masyaakat yang melakukan penundaan pembagian harta warisan ada dua sisi yang perlu diperhatikan, sisi positif dan sisi negatif. Sisi positif dari penundaan itu kalau cepat dilakukan pembagian warisan kesannya kematian itu sesuatu yang dituggu-tunggu, karena kebiasaan di masyarakat tidak buru-buru melaksanakan pembagian warisan. Dalam agama dianjurkan untuk melakukan sesuatu yang tidak menimbulkan suuddhan bagi sesama muslim yang lain, tidak ada suatu kewajiban menyegerakan pembahagian warisan, karna bukan bahagian dari tajhiz mayyit, dibagi ataupun tidak harta warisan itu memang sudah menjadi milik bersama (syirkah syuyu') seluruh ahli waris. Karna sifatnya syirkah salah seorang ahli waris yang ingin mengambil manfaat dari warasah (harta warisan) itu perlu penentuan haknya masing-masing sesuai dengan tuntunan agama, penentuan ini (pembahagian/taqsim) dibutuhkan bila ahli waris memang ingin memanfaatknnya, seperti menjual, menyewakan dan lain-lain, selama para ahli warist belum ingin memanfaatknnya maka tidak penyebab yang mendesak untuk disegerakan. ${ }^{39}$

Selanjutnya jika dilihat dari sisi negatifnya, pertama berefek kepada tidak bisa mengambil manfaat dari warasah itu, salah seorang ahli waris yang memanfaatkannya tanpa persetujuan ahli waris yang lain hukumnya haram dan semua ahli waris ikut menanggung dosa haram ini. Kedua, masalah penundaan warasah dari ahli waris satu

\footnotetext{
${ }^{37}$ Tgk. Ridwan, S.Pd, Ulama Kota Langsa, wawancara di Kantor Permusyawaratan Ulama Kota Langsa, 1 Februari 2018.

${ }^{38}$ Ibid.

39 Tgk. Murdani bin Muhammad, Pimpinan Dayah Futuhul Mu'arif Al Aziziyyah Kota Langsa, wawancara di Dayah Futuhul Mu'arif Al Aziziyyah Kota Langsa, 21 Juni 2018
} 


\section{Tahkím}

Vol. XIV, No. 1, Juni 2018

menjadi penyebab retak silaturrahmi pada ahli waris yang lain, putus silaturrahmi hukumnya haram, keharaman ini juga tanggung jawab bersama seluruh ahli waris, karna kebiasaan dalam masyarakat penundaan tingkat ahli waris pertama berlanjut sampai ke anak dari ahli warist yang pertama itu. Ketiga, terjadi pertumpahan darah dan ini yang ghalib (kebiasaan) dalam masyarakat, karna harta pada masyarakat awam menjadi tujuan hidup yang tidak siap kalah dan kurang sedikitpun. Membiarkan penundaan itu sama dengan membuat penyebab bagi hal-hal negatif diatasi. ${ }^{40}$

Dalam ilmu $u u l$ disebutkan "menghindari haram lebih baik daripada mencari kebaikan." Ditambah dengan kaedah fiqh yg lain "apabila dalam satu kasus ada kebaikan dan keburukan maka utamakan untuk menghindari suatu keburukan itu". Berdasarkan kaedah ini maka menurut Tgk Murdani warasah disegerakan untuk pembahagiannya.

Kemudian, Bapak Bustami mengatakan bahwa sebenarnya warisan tidak boleh ditunda-tunda, beliau, melakukan penundaan terhadap pembagian harta warisan adalah salah. Jadi begitu pewaris meninggal, maka langsung dibagikan sesuai hak masingmasing. Kalau tidak segera dibagikan harta warisan tersebut, nanti akan timbul dampak lain lagi, misalnya seorang pewaris meninggal dan meninggalkan anaknya. Pewaris meninggalkan sebuah usaha, sampai saat ini usaha tersebut masih dijalankan bersama, belum dibagikan. Nanti akhirnya baru timbul persoalan, seperti salah satu ahli waris meninggal. Jadi menurut pandangan beliau, harta warisan itu harus segera dibagikan. Karna kalau tidak dibagi, maka nanti harta warisan akan bercampur-campur. Jadi banyak faktor itu kenapa pembagian harta warisan itu ditunda, yang salah bukan masyarakat saja, tapi penyuluhan juga kurang memadai. ${ }^{41}$

Tgk Jarimin mengatakan bahwa tidak boleh menunda pembagian warisan, jika dilakukan maka berdosa. Seharusnya begitu pewaris sudah meninggal, maka harta warisan harus segera dibagikan dan tidak boleh ditunda-tunda. Kalau ditunda, maka dia akan berdosa karena itu hukum Allah. Apalagi terkadang banyak orang miskin yang menggantungkan harapan pada orang tuanya. Begitu orang tuanya meninggal, kadang ada satu anak yang mempunyai harta lebih, kemudian dia tidak langsung membagikan harta warisan orang tuanya. Seharusnya langsung dibagi. Karna faraidh. Demikian menurut pandangan beliau. ${ }^{42}$

Kemudian terkait langkah yang harus dilakukan agar masyarakat tidak lagi melakukan penundaa terhadap pembaian harta warisan, beliau menyatakan bahwa masyarakat harus tau hukum. Kemudian belajar ilmu agama yang berhubungan dengan warisan. Sebenarnya bukan hanya di pesantren saja, di sekolah pun harus diterapkan pemahaman tentang warisan. Maka harus diberikan judul-judul pelajaran tentang warisan agar jika ada orang yang meninggal, masyarakat langsung membagikan harta warisan dan tidak menundanya. ${ }^{43}$

\footnotetext{
${ }^{40}$ Ibid.

${ }^{41}$ Bustami A Latief, SH, MA., Ketua Pimpinan Daerah Muhammadiyah Kota Langsa, wawancara di Universitas Samudera Langsa, 21 Juni 2018.

42 Tgk Jarimin, Pimpinan Dayah Seuramoe Mekkah Langsa sekaligus oengurus cabang Nadhlatul Ulama Langsa, wawancara di Dayah Seuramoe Mekkah Langsa, 21 Juni 2018.

${ }^{43}$ Ibid.
} 


\section{Tahkím}

Vol. XIV, No. 1, Juni 2018

Beliau memaparkan contoh kasus, misalnya istri meninggal, tinggallah suami dan ada anak. Kemudian suami menikah lagi dengan istri yang baru dan membawa istri baru tersebut ke rumah, padahal itu harta tersebut milik istri yang lama. Seharusnya langsung dibagikan harta warisan lebih dulu kepada anak-anak. Kalau sudah ada istri yang baru, itu nanti perhitungan yang lain nanti. Begitu juga kalau seorang suami meninggal, tinggal istri dan anak. Nanti jika ada anak dengan suami yang baru maka dianggap harta warisan yang lama juga ada bagian anak dari suami yang baru, padahal tidak. Maka demikian, saya rasa harus diajarkan hukum baik dari pendidikan sekolah supaya tau hukum warisan. ${ }^{44}$

Tgk Salahuddin Muhammad mengatakan bahwa masyarakat yang melakukan penundaan terhadap pembagian harta warisan karena dua hal. Pertama penundaan itu alasannya ada ahli waris yang lain yang tidak taat hukum. Kedua, penundaan itu karena dalam faraidh ada dua cara. Cara yang pertama yaitu tasamuh, makna tasamuh dibagi dengan cara muwafakat keluarga. Umpamanya laki-laki dan perempuan dibagi sama. Tata cara yang kedua sesuai faraidh, laki-laki bahagiannya lebih besar daripada perempuan. Untuk mencapai kesepakatan itu terkadang terjadi penundaan. Mengenai hukum melakukan penundaan terhadap pembagian warisan, beliau mengatakan bahwa berdosa, karna akibat atau efeknya besar. Seharusnya begitu seseorang meninggal langsung difaraidh, dibagi setelah diselesaikan hutang-hutang yang meninggal itu. Baik hutang dengan Allah ataupun hutang dengan manusia, yang tinggal langsung dibagi. Karna efeknya begini, kalau yang jatah bapaknya udah dapat karna ini penundaan begitu meninggal bapaknya, harta warisan dari neneknya yang menjadi bagian ayahnya belum dibagi, apalagi ada ahli waris lain yang juga meninggal hingga dalam faraidh disebut dengan munasakhat sudah bertindih. Cara menyelesaikan harta warisannya sudah rumit, kalau bukan ahli faraidh yang menyelesaikan masalah warisan ini. Kadang bisa mengakibatkan seseorang diberikan hak padahal ia tidak mendapatkan hak. Inilah akibat yang dosa tadi. ${ }^{45}$

Selanjutnya beliau menambahkan bahwa ada cara atau langkah agar masyarakat tidak melakukan penundaan pembagian harta warisan, yaitu dengan adanya ilmu. Masyarakat yang melakukan penundaan pembagian harta warisan itu karna tidak takut pada Allah dan pemahaman mereka tentang penundaan harta warisan itu dianggap sepele. $^{46}$

Menurut penulis, setelah melihat dan memahami beberapa pandangan para ulama di Kota Langsa, baik Majelis Permusyawaratan Ulama Kota Langsa, Pimpinan Dayah, Pimpinan Daerah Muhammadiyah dan Pengurus Cabang Nadhlatul Ulama Kota Langsa, sepakat mengatakan bahwa berdosa hukumnya apabila masyarakat melakukan penundaan pembagian harta warisan, terlebih jika penundaan pembagian warisan itu menimbulkan dampak negatif para ahli waris yang ada.

Penulis juga menemukan ayat yang memaparkan apa-apa saja ketentuan yang harus dilaksanakan ketika seseorang telah meninggal dunia, yaitu memberikan harta warisan kepada ahli waris yang berhak setelah dipenuhi wasiat pewaris dan dibayarkan seluruh hutang pewaris.

\footnotetext{
${ }^{44}$ Ibid.

${ }^{45}$ Tgk Salahuddin Muhammad, S.Ud., Pimpinan Dayah Bustanu Malikulssaleh Ruhul Quddus Langsa, wawancara di Dayah Bustanu Malikulssaleh Ruhul Quddus Langsa, 19 Juni 2018.

${ }^{46}$ Ibid.
} 


\section{Tahkím}

Vol. XIV, No. 1, Juni 2018

Allah SWT telah menyebutkan tindakan tersebut dalam Surah An-Nisa' ayat 11 dan 12:

Artinya:

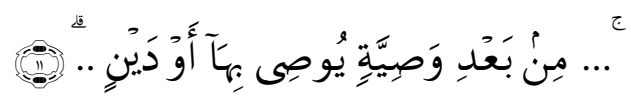

“...(pembagian-pembagian tersebut di atas) sesudah dipenuhi wasiat yang ia buat atau (dan) sesudah dibayar hutangnya....”. (Q.S An-Nisa: 11). ${ }^{47}$

Selanjutnya Allah SWT berfirman:

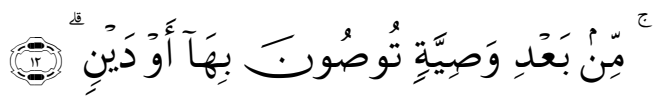

Artinya:

“... sesudah dipenuhi wasiat yang kamu buat atau (dan) sesudah dibayar hutanghutangmu...". (Q.S An-Nisa: 12). ${ }^{48}$

Dalam kedua ayat tersebut Allah menyatakan bahwa harta warisan menurut bagian yang ditentukan dilakukan sesudah diberikan wasiat yang diwasiatkan dan sesudah dibayarkan hutang yang dibuat pewaris. Ketentuan ini dalam ayat 11 disebutkan satu kali dan dalam ayat 12 disebutkan sebanyak tiga kali.

Kemudian terdapat hadis yang menganjurkan untuk memberikan harta warisan kepada ahli waris, yaitu :

Artinya:

$$
\text { س : الحقو ا الفر ائض بأهلها فما بقي فلأولى رجل ذكر } 49
$$

"Dari Ibn Abbas Rasulullah bersabda: berikanlah harta warisan kepada yang berhak (asbah al-furud), jika ada yang tersisa berikanlah kepada ahli waris laki-laki (ashabah). (HR. Mutaffaq alaih)".

Terdapat juga beberapa kaidah fikih yang menyatakan bahwa menolak kerusakan lebih didahulukan daripada mengambil manfaat. Yaitu:

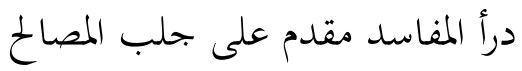

Artinya:

"Menghilangkan mafsadat lebih didahulukan daripada mengambil manfaat."

Kandungan kaidah ini menjelaskan bahwa jika terjadi perlawanan antara kerusakan dan kemaslahatan pada suatu perbuatan, dengan kata lain jika satu perbuatan ditinjau dari satu segi terlarang karena mengandung kerusakan dan ditinjau dari segi yang lain mengandung kemaslahatan, maka segi larangannya yang harus didahulukan untuk di tinggalakan.

Menurut penulis, berdasarkan kaidah ini dapat dikatakan bahwa melakukan penundaan terhadap pembagian harta warisan lebih baik ditinggalkan karena dampak negatifnya lebih besar daripada dampak positif yang bisa diambil oleh masyarakat, dengan demikian sebaiknya masyarakat langsung melakukan pembagian harta warisan ketika pewaris sudah meninggal dan sudah diselesaikan biaya pengurusan jenazah, pembayaran wasiat dan pembayaran hutang.

${ }^{47}$ Departemen Agama RI, Al-Qur'an dan Terjemahnya (Bandung: CV Penerbit Diponegoro, 2000), h. 62 .

${ }^{48}$ Ibid., h. 63.

${ }^{49}$ Muhammad ibn Ali al-Syaukani, Nail al-Autar min Ahadits Sayyid al-Akhyar Syarh Muntaqa al-Akhbar. Juz 6 hadis no. 2542(Beirut: Dar al-Khair, 1996)., h. 459. 


\section{Tahkím}

Vol. XIV, No. 1, Juni 2018

Kompilasi Hukum Islam (KHI) juga dijelaskan mengenai hal-hal yang harus dilakukan terhadap harta peninggalan pewaris sebagaimana yang tertulis dalam pasal 187 sebagai berikut: ${ }^{50}$

\section{Pasal 187}

(1) Bilamana pewaris meninggalkan warisan harta peninggalan, maka oleh pewaris semasa hidupnya atau oleh para ahli waris dapat ditunjuk beberapa orang sebagai pelaksana pembagian harta warisan dengan tugas:

a. mencatat dalam suatu daftar harta peninggalan, baik berupa benda bergerak maupun tidak bergerak yang kemudian disahkan oleh para ahli waris yang bersangkutan, bila perlu dinilai harganya dengan uang;

b. menghitung jumlah pengeluaran untuk kepentingan pewaris sesuai dengan Pasal 175 ayat (1) sub a, b, dan c.

(2) Sisa dari pengeluaran dimaksud di atas adalah merupakan harta warisan yang harus dibagikan kepada ahli waris yang berhak.

Selanjutnya dalam Kompilasi Hukum Islam (KHI) juga dijelaskan mengenai halhal yang harus dilakukan jika ada salah satu keluarga yang tidak mau membagikan harta warisan seperti dalam pasal 188 , sebagai berikut: ${ }^{51}$

\section{Pasal 188}

Para ahli waris baik secara bersama-sama atau perseorangan dapat mengajukan permintaan kepada ahli waris yang lain untuk melakukan pembagian harta warisan. Bila ada diantara ahli waris yang tidak menyetujui permintaan itu, maka yang bersangkutan dapat mengajukan gugatan melalui Pengadilan Agama untuk dilakukan pembagian warisan.

Pasal yang tertera dalam Kompilasi Hukum Islam (KHI) tersebut seharusnya dipahami oleh masyarakat Kota Langsa agar lebih mengetahui dan melaksanakan pembagian warisan setelah pewaris meninggal sehingga dampak negatif dari penundaan pembagian warisan dapat dihindarkan.

\section{Kesimpulan}

Berdasarkan pembahasan di atas dapat disimpulkan bahwa dalam pelaksanaan pembagian warisan pada masyarakat muslim di Kota Langsa, terdapat beberapa cara yang dilakukan masyarakat dalam menyelesaikan permasalahan dalam pembagian warisan, yaitu dengan cara musyawarah atau kekeluargaan baik melibatkan keluarga saja maupunpun melibatkan perangkat desa, dan cara terakhir yaitu melalui Mahkamah Syar'iyah Langsa. Banyak masyarakat kota Langsa yang menunda-nunda membagikan harta warisan. Dari 42 kasus yang masuk dalam Mahkamah Syar'iyah, 36 kasus diantaranya berupa penetapan ahli waris dan 6 kasus lainnya berupa konflik yang disebabkan dari penundaan pembagian warisan yang dilakukan oleh masyarakat. Selanjutnya terdapat 7 kasus yang tidak sampai ke Mahkamah, masalah tersebut selesai di desa. Faktor atau alasan masyarakat Kota Langsa menunda pembagian warisan yaitu: kesepakatan seluruh ahli waris; ahli waris banyak yang masih kecil atau belum waktunya mendapatkan warisan; beberapa pihak ingin menguasai harta warisan

\footnotetext{
${ }^{50}$ Undang-Undang R.I Nomor 1 Tahun 1974..., h. 379-380.

${ }^{51}$ Ibid.
} 


\section{Tahkím}

Vol. XIV, No. 1, Juni 2018

sehingga tidak ada atau ditundanya pembagian warisan itu; sebagian besar masyarakat menganggap membahas masalah warisan setelah pewaris meninggal adalah tabu; masih hidupnya salah satu ayah atau ibu pewaris sehingga ditunda pembagian warisan. Dampak penundaan pembagian warisan yang dilakukan masyarakat di Kota Langsa, yaitu sebagai berikut: terjadi konflik diantara ahli waris, baik itu konflik ringan sampai konflik berat; adanya hak-hak ahli waris yang berkurang dari bagian yang seharusnya diterima; adanya ahli waris yang tidak bisa merasakan harta warisan karena meninggal sebelum harta warisan itu sempat dibagikan; putusnya silaturahmi atau persaudaraan antara ahli waris karena perebutan harta warisan. dampak positif.

\section{DAFTAR PUSTAKA}

Ahmad, T. Mahmud. Ilmu Faraidh Praktis, Banda Aceh: Yayasan Pena, 2012

Arfa, Faisar Ananda. Metodologi Penelitian Hukum Islam, Jakarta: Kencana, 2016.

Budiono. A. Rachmad. Pembaruan Hukum Kewarisan Islam di Indonesia, Bandung: PT. Citra Aditya Bakti, 1999.

Bungin, Burhan. Metodologi Penelitian Kualitatif, Jakarta: PT.Raja Grafindo Persada, 2008.

------. Metodologi Penelitian Kuantitatif: Komunikasi, Ekonomi dan Kebijakan Publik serta Ilmu-Ilmu Sosial Lainnya, Jakarta: Kencana Prenada Media Group, 2009.

Dahlan, Abdul Aziz. Ensiklopedi Hukum Islam, Jakarta: Ichtiar Baru van Hoeve, 1996.

Departemen Agama RI. Al-Qur'an dan Terjemahnya, Bandung: CV Penerbit Diponegoro, 2003.

Departemen Pendidikan Nasional. Kamus Besar Bahasa Indonesia Pusat Bahasa, Jakarta: PT Gramedia Pustaka Utama, 2008.

Fuady, Munir. Dinamika Teori Hukum, Bogor: Ghalia Indonesia, 2010.

Ghazali, al-Qadhi al-Mustasyar al-Syaikh Husain Yusuf. Al-Mawarist 'Ala Al-Mazahib Al-Arba'ah, Beirut: Dar al-Fikri, 2003.

Al-Ghazali. Al-Musthashfa, Beirut: Dār Ihya Turats Al-Arabi, 1997.

Hasanah, Amalia. Kamus Besar Bahasa Arab, Yogyakarta: Pustaka Widyatama, 2013.

Ibn Al-Hajjaj, Muslim. ahih Muslim, Jilid III. Kairo: Al Halabi, 1955.

Khalifah, Muhammad Thaha Abul Ela. Pembagian Warisan Berdasarkan Syariat Islam, Solo: Tiga Serangkai, 2007.

Kementerian Pendidikan dan Kebudayaan RI. Kamus Bahasa Indonesia untuk Pelajar, Jakarta: Badan Pengembangan dan Pembinaan Bahasa, 2011.

Komite Fakultas Syariah Universitas Al-Azhar, Mesir. Hukum Waris. Terj. Addys Aldizar dan Fathurrahman, Jakarta: Senayan Abadi Publishing, 2004.

Latif, Abdul. Pendidikan Bebasis Nilai Kemasyarakatan, Bandung: Refika Aditama, 2009. 


\section{Tahkím}

Vol. XIV, No. 1, Juni 2018

Lubis, Suhrawardi K dan Simanjuntak, Komis. Hukum Waris Islam: Lengkap dan Praktis, Jakarta: Sinar Grafika, 2008.

Nasution. Metode Research Penelitian Ilmiah, Jakarta: Bumi Aksara 2001.

Mubarak, Jaih. Kaidah Fikih, Sejarah dan Kaidah-Kaidah Asasi, Jakarta: PT RajaGrafindo, 2002.

Muhibbin, dan Abdul Wahid. Hukum Kewarisan Islam Sebagai Pembaruan Hukum Positif di Indonesia, Jakarta: Sinar Grafika, 2011.

Munawir, Ahmad Warson. Kamus Al-Munawwir Arab Indonesia Terlengkap, Yogyakarta: Pustaka Progresif, 1997.

Mursyiddin. Membuat Syariat Islam Bekerja: Mpu Dan Perananya Dalam Pembentukan Qanun Jinayat Di Aceh. Langsa: Zawiyah Serambi Ilmu Pengetahuan, 2015.

Rahman, Fatchur. Ilmu Waris, Bandung: PT. Alma'arif, 1971.

Republik Indonesia. Undang-Undang R.I Nomor 1 Tahun 1974 tentang Perkawinan dan Kompilasi Hukum Islam. Bandung: Citra Umara, 2000.

Saebani, Beni Ahmad. Fiqh Mawaris, Bandung: Pustaka Setia, 2009.

Sarwono, Sarlito Wirawan. Psikologi Sosial Psikologi Kelompok dan Psikologi Terapan, Jakarta: Balai Pustaka, 1999.

Sufyan, Muhammad Suhaili. Fiqh Mawaris Praktis: Perbandingan Empat Mazhab dan Kompilasi Hukum Islam Indonesia, Bandung: Citapustaka Media Perintis, 2012.

Suparman, Eman. Hukum Waris Indonesia dalam Perspektif Islam, Adat, dan BW, Bandung: PT Refika Aditama, 2007.

Syarifuddin, Amir. Hukum Kewarisan Islam, Jakarta: Prenada Media, 2004.

Ash-Shabuni, Ali. Al-Mawaris, Beirut: Alamul Kutub, t.th.

Ash-Shabuni, Muhammad Ali. Pembagian Waris Menurut Islam, Jakarta: A.M. Basamalah Gema Insani Press, 1995.

Al-Syatibi. Al Muwafaqaat fi Ushul As Syariah, Beirut Daaral Kutub Al Ilmiyah, 2007.

At Tirmidzi. Al Jami’ al- ahih, Jilid IV, Beirut: Dar al Kutub Ilmiyah, 1937.

Umam, Dian Khairul. Fiqih Mawaris. Bandung: CV Pustaka Setia, 2000.

Umar, Mukhsin Nyak. Rekonstruksi Pemikiran Hukum Islam di Indonesia: Pendekatan Al-Maslahah Al-Mursalah, Banda Aceh: Yayasan Pena, 2006.

Al-Utsaimin, Muhammad bin Shalih. Panduan Waris Empat Madzhab. Terj. Wahyudi Abdurrahim, Jakarta: Al-Kautsar, 2009.

Al-Youbi. Maqashid Syariah wa Alaqatuha bi Al-Adillah Al-Syar'iyyah, Riyadh: Daaar Ibnu Jauzi, 2008.

Zahari, Ahmad. Tiga Versi Hukum Kewarisan Islam: Syafi'i, Hazairin dan KHI, Pontianak: Romeo Grafika, 2003 